\title{
Development of a Virtual Laboratory for Biochemistry Practicum during the Covid-19 Pandemic
}

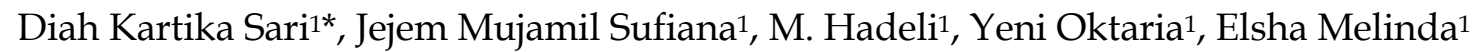 \\ ${ }^{1}$ Chemistry Education, Universitas Sriwijaya, Indralaya, Indonesia
}

DOI: $10.29303 /$ jppipa.v8i1.1171

\section{Article Info}

Received: November 26, 2021

Revised: Janaury 13, 2022

Accepted: January 18, 2022

Published: January 31, 2022

\begin{abstract}
Practical lectures should be held face-to-face. The COVID-19 outbreak that hit Indonesia and the world in general made practicum lectures unable to run as they should. This study aims to develop a Virtual Laboratory in the Practicum course. The purpose of this research is to develop a Virtual Laboratory in Biochemistry Practicum. This research is development research with the ADDIE development model from Dick and Carry, namely a development model consisting of five stages which include analysis, design, development, implementation and evaluation. The results of laboratory development validation show the Aiken coefficient of 0.87 for material experts and 0.92 for media experts. The results of the implementation show the practicality of $94.45 \%$. It can be concluded that the virtual laboratory developed in the Biochemistry practicum is valid and practical.
\end{abstract}

Keywords: Virtual laboratory; Covid 19; Development research

Citation: $\quad$ Sari, D. K., Sufiana, J. M., Hadeli, M., Melinda, E., \& Oktaria, Y. (2022). Development of a Virtual Laboratory for Biochemistry Practicum during the Covid- 19 Pandemic. Jurnal Penelitian Pendidikan IPA, 8(1), $277-282$. https://doi.org/10.29303/jppipa.v8i1.1171

\section{Introduction}

Practical Lectures should be held face-to-face. Practicum is a lecture activity where there is a face-toface meeting between lecturers and students that emphasizes psychomotor, cognitive and affective aspects. In the Biochemistry practicum course, students are expected to be able to do practical work so that their psychomotor abilities can be seen, of course, supported by the cognitive and affective aspects that exist within them. The Biochemistry Practicum has been designed on a project-based basis that utilizes local materials (PjBLLM) (Sari, et.al, 2018).

Preliminary studies on Biochemistry practicum on the topic of quantitative analysis of PjBLLM proteins can improve creative thinking skills (Sari, et.al, 2017). Due to the COVID-19 outbreak in 2020, any lectures, including Biochemistry practicum lectures, must be carried out online.

PjBLLM Biochemistry practicum lectures can be done online, one of which is by developing a virtual laboratory. Virtual laboratory is a series of laboratory learning innovations in the form of software (Setiono,
2019; Orgaz, et al, 2018; Almeida \& Simoes, 2019; Aljuhani, et al, 2018). Virtual laboratory or virtual laboratory is a practicum learning development that is currently being researched in integration efforts use of information technology (Dwiningsih, et al, 2018; Herga, \& Dinevski, 2012). It is based on the premise that information technology provides an alternative learning environment that can facilitate meaningful learning (Gambari, et.al, 2018; Vasiliadou, 2020; Fadly, et al, 2021; Liu, et al, 2015). The development of virtual laboratories is important to develop because the use of virtual laboratories has been proven to improve students' understanding (Darby-White, et.al, 2019), improve students' thinking skills (Hess, 2014; Widowati, et.al, 2017), improve scientific literacy (Putri, et al., 2021), enhance students' thinking abilities, skills, and scientific attitudes (Ramadhan \& Irwanto, 2017) and critical thinking (Elisa, et al, 2020). Beside that virtual experimental platform in chemistry laboratory education can impact on experimental selfefficacy (Kolil, et al., 2020).

The development of virtual laboratories can still convey important concepts to students (Quesada, 2020). 
Furthermore, the virtual laboratory has been combined with certain learning models such as Discovery Learning to improve the Physics Competence of High School Students (Masril, et.al, 2018) and virtual laboratory has been equipped LKM (Hidayati \& Masril, 2019).

From the description of the background above, there have been many studies on virtual laboratories, but there has been no research that has developed a project-based virtual laboratory using local materials. Project-Based Virtual Laboratory with Local Materials in Biochemistry Practicum by utilizing local materials around students can be a solution when face-to-face learning cannot be carried out. The novelty of this research is that online learning is obtained using a Project-Based Virtual Laboratory with Local Materials in the Biochemistry Practicum.

\section{Method}

This research is development research. This study aims to develop a virtual laboratory in practical lectures that will meet the valid, practical and effective criteria. This research procedure adapts the ADDIE development model from Dick and Carry, which is a development model consisting of five stages which include analysis, design, development, implementation and evaluation.

This research procedure adapts the ADDIE development model from Dick and Carry, which is a development model consisting of five stages which include analysis, design, development, implementation and evaluation. The research procedure can be seen in Figure 1.

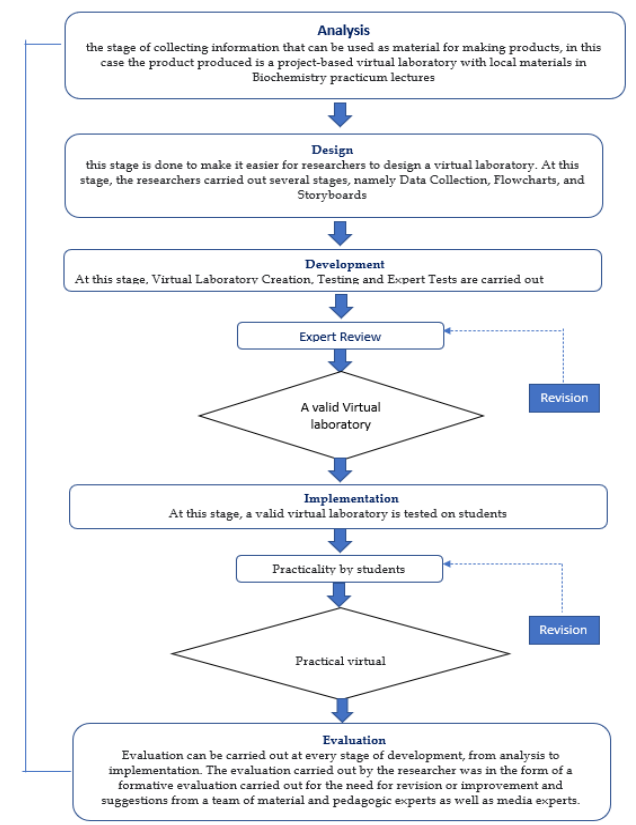

Figure 1. Virtual laboratory development research research procedure with ADDIE model
This research step is limited to the pilot stage so that this study does not examine the effect of the product on student abilities, this is in accordance with the research objective, namely to produce a valid and practical virtual laboratory. Data collection techniques that will be used by researchers are as follows:

\section{Interview}

This interview was conducted with students of the Biochemistry Practicum to complete the data regarding the needs analysis needed to determine the state of learning and the need for the development of a virtual laboratory. In terms of implementation, the interviews conducted by researchers were semi-structured interviews.

\section{Expert Validation}

Expert validation is carried out at the development stage after the designed product has been completed. Validation sheets are given to validators consisting of a team of experts. The expert team consists of material experts and media experts. This stage aims to determine the feasibility of the virtual laboratory that has been develop

\section{Questionnaire}

Data collection in the form of filling out questionnaires by lecturers and students is carried out at the implementation stage. Questionnaires are used to see the practicality of the virtual laboratory that has been developed by researchers by looking at the responses from students and lecturers.

\section{Result and Discussion}

The following presents the data obtained in accordance with the development research procedures that have been carried out.

\section{Analysis}

At the analysis stage, the researchers obtained the following results: (1) Overall, students have difficulty doing Biochemistry practicum during the COVID-19 pandemic; (2) There is no virtual laboratory for Biochemistry practicum in the Unsri Chemistry Education study program; (3) Students are accustomed to using technology such as Android phones and others.

\section{Design}

At this stage, the researcher obtained a design for a virtual laboratory that would be developed in the form of practicum procedures and storyboards. 


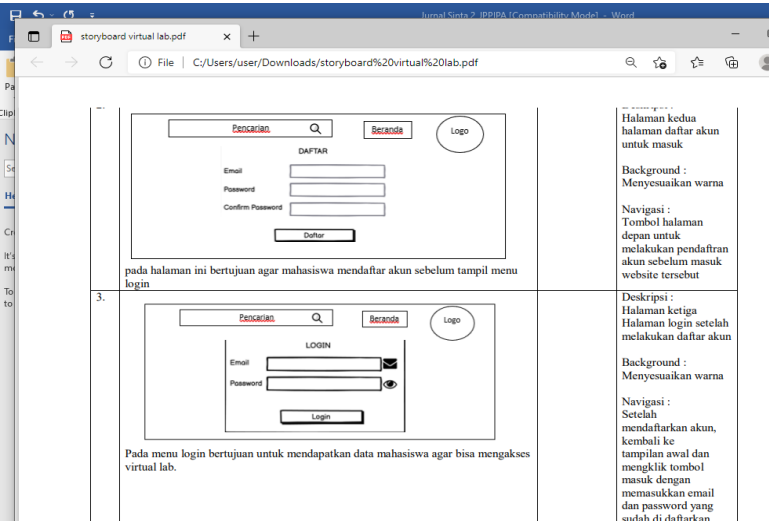

Figure 2. Storyboard Virtual laboratory

\section{Development}

\section{Virtual Laboratory Creation}

At this stage, a virtual laboratory is generated that is in accordance with the researcher's design.

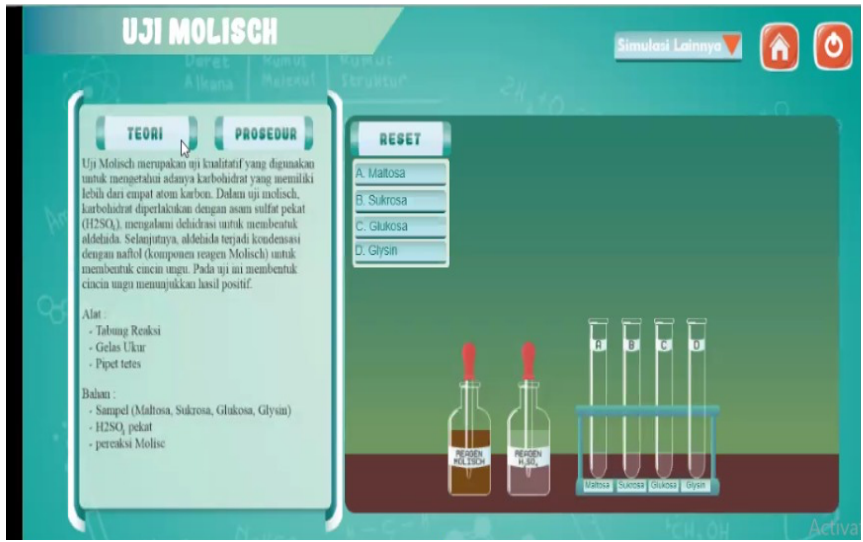

Figure 3. Virtual laboratory

2. Testing

The results of the testing can be seen in Table 1.

Table 1. The result of Testing

\begin{tabular}{ll}
\hline Before revision & After revision \\
\hline $\begin{array}{l}\text { Explanatory material is too short } \\
\text { and not sourced }\end{array}$ & Has been added \\
$\begin{array}{l}\text { There is no reaction mechanism } \\
\text { every practicum }\end{array}$ & Has been added \\
\hline
\end{tabular}

\section{Expert test}

1) Material validation

The results obtained from material validation can be seen in Table 2 .

Table 2. Comments and Suggestions from Material validators

\begin{tabular}{ll}
\hline Before revision & After revision \\
\hline There is no explanation that supports & Has been added \\
the results of the practicum in the & \\
virtual laboratory & \\
The color change is not clear yet & tried to fix \\
\hline
\end{tabular}

The results of material validation using the $\mathrm{V}$ Aiken formula can be seen in the Table 3.

Table 3. The Results of Material Validation

\begin{tabular}{llll}
\hline Validator & Score & average & Category \\
\hline Expert 1 & 0.82 & 0.87 & high \\
Expert 2 & 0.92 & & \\
\hline
\end{tabular}

Improvements to the material contained in the virtual laboratory application have been improved according to comments and suggestions from material experts. The virtual laboratory application validity assessment questionnaire that has been filled out by a material expert consisting of two aspects assessed with 13 descriptors is then analyzed using the $\mathrm{V}$ Aiken formula to determine whether the material contained in the virtual laboratory application is valid and the final score is 0.87 with a high category so that it can be said that the material in the developed virtual laboratory application is valid and in accordance with the introduction of chemical laboratory equipment, and the virtual laboratory is feasible to proceed to the next stage, namely testing.

\section{2) Media Validation}

The results obtained from media validation can be seen in Table 4 below.

Table 4. Comments and Suggestions from Media validators

\begin{tabular}{lc}
\hline Before revision & After revision \\
\hline $\begin{array}{l}\text { The Background is not attractive, } \\
\text { because it's just plain colors. }\end{array}$ & Tried to fix \\
\hline
\end{tabular}

The results of media validation using the $\mathrm{V}$ Aiken formula can be seen in the Table 5 .

Table 5. The Results of Media Validation

\begin{tabular}{llll}
\hline Validator & score & Average & Category \\
\hline Expert 1 & 0.95 & 0.92 & High \\
Expert 2 & 0.89 & & \\
\hline
\end{tabular}

Media assessment in virtual laboratory applications for the introduction of chemical laboratory tools in terms of learning media programming, text on learning media, visual display of learning media, presentation of images or videos on learning media, navigation buttons and development of science and technology. The results of the assessment with media experts contained suggestions and comments, namely the appearance of the background or the background looks less attractive because it only displays plain colors and it would be better if all laboratory equipment was equipped with a video on how to use it. Improvements to the media contained in the virtual laboratory application have been improved according to suggestions and comments from media experts. The 
virtual laboratory application validity assessment questionnaire which consists of two aspects with 12 descriptors to be assessed has been filled in by media experts, the results of the assessment are then analyzed by researchers using the Vaiken formula to determine whether or not the virtual laboratory application is valid and the final score obtained which is 0.92 with a high category so that it can be said that the virtual laboratory application developed is valid and feasible to proceed to the next stage, namely testing.

\section{Implementation}

Activities at the implementation stage can be seen in Figure 4 below.

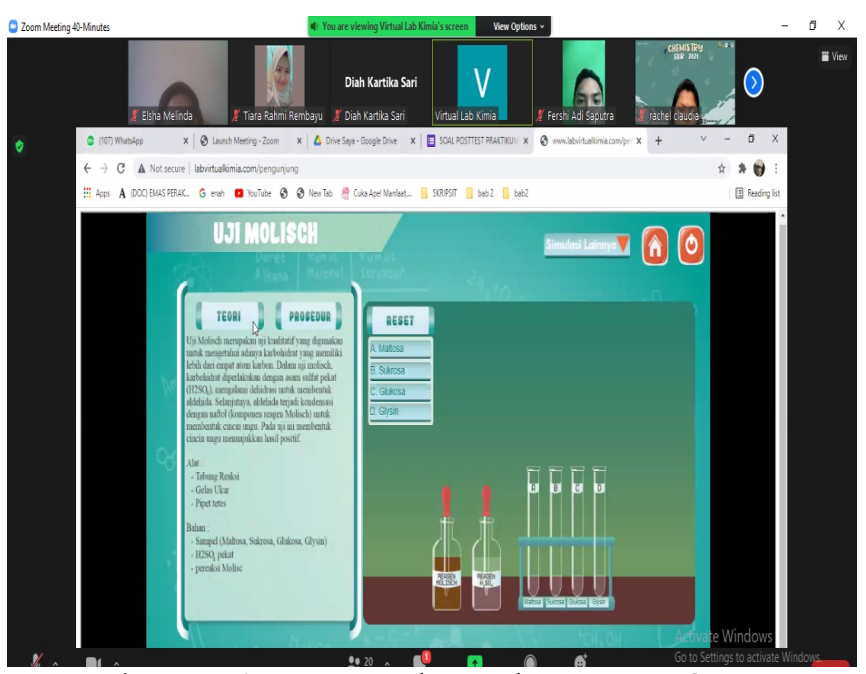

Figure 4. Activities at the implementation Stage

The implementation stage is carried out to determine the level of practicality of the virtual laboratory application which has previously been validated by material experts and media experts. The results of expert validation obtained prototype II which will be tested in small groups involving nine students. The nine students consisted of two high-ability students, five medium-ability students, and low-ability students. The ability of the selected students is seen from the GPA. The nine students were then given a virtual laboratory application. The results of the implementation using the Guttman scale can be seen in Table 6.

Table 6. Results of the Percentage of Practicality Using the Guttman Scale

\begin{tabular}{lllll} 
Questionnaire & \multicolumn{2}{l}{ Amount } & Percentage \\
\cline { 2 - 5 } Statement & Yes & No & Yes $(\%)$ & No $(\%)$ \\
\hline 1 & 9 & 0 & 100 & 0 \\
2 & 8 & 1 & 88.90 & 11.10 \\
3 & 9 & 0 & 100 & 0 \\
4 & 9 & 0 & 100 & 0 \\
5 & 9 & 0 & 100 & 0 \\
6 & 9 & 0 & 100 & 0 \\
7 & 8 & 1 & 88.90 & 11.10 \\
8 & 9 & 0 & 100 & 0 \\
9 & 8 & 1 & 88.90 & 11.10 \\
10 & 6 & 3 & 66.70 & 33.30 \\
11 & 9 & 0 & 100 & 0 \\
12 & 9 & 0 & 100 & 0 \\
Average & & & 94.45 & \\
\hline
\end{tabular}

Based on the results of the assessment obtained from the implementation stage, the percentage results obtained with an average score of $94.45 \%$ with a very practical category which means the Virtual Laboratory is significantly practical. It can be concluded that this Virtual Laboratory of Biochemistry Practicum is very practical and can be used in learning Biochemistry Practicum. With comments and suggestions that the Virtual Laboratory is very interesting in delivering material so that it stimulates students to increase their enthusiasm for learning and add insight into the Biochemistry Practicum. Comments and suggestions at the implementation stage can be seen in Table 7 .

Table 7. Comments and Suggestions from Students at the Implementation Stage

\begin{tabular}{|c|c|}
\hline Student & Comments and Suggestions \\
\hline \multirow[t]{2}{*}{ Student 1} & Virtual Lab is good and very interesting. \\
\hline & The suggestion is to change or add two or more background sounds to make it even more interesting \\
\hline Student 2 & $\begin{array}{l}\text { The use of the Virtual Laboratory is good, both in delivering material and understandable. Suggestions in } \\
\text { the future in the delivery of material please be slowed down. }\end{array}$ \\
\hline Student 3 & $\begin{array}{l}\text { The use of the Virtual Laboratory is good, but there are some things that often occur when virtual, such as } \\
\text { the sound is too big, the signal is constrained so that it reduces understanding when learning. }\end{array}$ \\
\hline Student 4 & $\begin{array}{l}\text { Virtual Laboratory is interesting enough to add a sense of desire to do practical work. However, the } \\
\text { appearance/sound of the Virtual Laboratory is too monotonous so that it can be varied again. }\end{array}$ \\
\hline Student 5 & The Virtual Laboratory is good, it can be used as learning media during this pandemic. \\
\hline Student 6 & $\begin{array}{l}\text { Virtual Laboratories can help with practical activities that are difficult to carry out online. Suggestion } \\
\text { material can be reproduced even more. }\end{array}$ \\
\hline Student 7 & The Virtual Laboratory is good to use but the music is too big. \\
\hline Student 8 & The Virtual Laboratory is good and can help in understanding the material for the Biochemistry Practicum. \\
\hline \multirow[t]{2}{*}{ Student 9} & With the Virtual Laboratory, you can directly see the Biochemistry Practicum. \\
\hline & The suggestion is to be further improved and the material to be reproduced even more. \\
\hline
\end{tabular}




\section{Evaluation}

Evaluation is carried out by researchers at each stage of research development to improve the resulting product development. The development of a virtual laboratory in the Biochemistry practicum can help practicum activities that are not possible to do directly during covid 19 pandemic. In line with previous research, the Biochemistry virtual laboratory can build students' understanding, thinking skills and convey important concepts (Darby-White, et al, 2019; Widowati, et al, 2017; Quesada, 2020). This virtual laboratory will be more effective if it is associated with the environment (Dwiningsih, et al, 2018) and learning model (Masril, et al, 2018).

\section{Conclusion}

A study has been conducted to develop a virtual laboratory. Based on the findings and discussion, it can be concluded that the virtual laboratory was proven by Aiken value obtained was material expert and media expert of +0.87 and +0.92 which means that it can be considered as valid for all validated components. The results of the implementation show that the practicality reaches $94.45 \%$. This means that the virtual laboratory is very practical and can be used in learning Biochemistry Practicum.

\section{Acknowledgements}

The research of this article was funded by DIPA of Public Service Agency of Universitas Sriwijaya 2021.SP DIPA-023.17.2.677515/2021, On November 23,2020. In accordance with the Rector's Decree Number: 0022/UN9/SK.LP2MP.PT/2021, On July 21, 2021.

\section{References}

Aljuhani, K., Sonbul, M., Althabiti, M., and Meccawy, M. (2018). Smart Learning Environments. Vol 5:16. https://doi.org/10.1186/s40561-018-0067-9

Almeida, F., \& Simoes, J. (2019). The Role of Serious Games, Gamification and Industry 4.0 Tools in The Education 4.0 Paradigm. Contemporary Educational Technology. 10(2): 120-136. http://dx.doi.org/10.30935/cet.554469

Darby-White, T., Wicker, S., \& Diack, M. (2019). Evaluating the Effectiveness of Virtual Chemistry Laboratory (VCL) in Enhancing Conceptual Understanding: Using VCL as Pre-Laboratory Assignment. Journal of Computers in Mathematics and Science Teaching, 38(1), 31-48. Retrieved from https://www.learntechlib.org/primary/p/172833 L

Dwiningsih, K., Sukarmin, Muchlis, \& Rahma, P. T. (2018). Pengembangan Media Pembelajaran Kimia
Menggunakan Media Laboratorium Virtual Berdasarkan Paradigma Pembelajaran Di Era Global. Jurnal Teknologi Pendidikan, 06(02), 156-176. https://doi.org/10.31800/jtp.kw.v6n2.p156--176

Elisa, E., Wiratmaja, I. G., Nugraha, I. N. P., \& Dantes, K. R. (2020). Pengembangan Laboratorium Virtual Kimia Teknik untuk Meningkatkan Keterampilan Berpikir Kritis dan Proses Sains Mahasiswa. Journal of The Indonesian Society of Integrated Chemistry. $12(2)$ : 55-61. https://doi.org/https://doi.org/10.22437/jisic.v1 2i2.11243

Fadly, A. A., Yusuf, A. M., Widyaningsih, A., Sari, D. Y., Azizah, D. S., Rumpoko, G., Arrarrona, M. D., Munsyarikha, N., Salsabila, T. I., \& Wagistina, S. (2021). Persepsi dan tingkat pengetahuan mahasiswa terhadap perkuliahan dalam jaringan di Progam Studi Pendidikan Geografi Universitas Negeri Malang. Jurnal Integrasi Dan Harmoni Inovatif Ilmu-Ilmu Sosial. 1(5): 658-665. https://doi.org/10.17977/um063v1i5p658-665

Gambari, A. I., Kawu, H., \& Falode, O. C.(2018). Impact of Virtual Laboratory on the Achievement of Secondary School Chemistry Students in Homogeneous and Heterogeneous Collaborative Environments. Contemporary Educational Technology, 9(3), 246-263. http://dx.doi.org/10.30935/cet.444108

Herga, N. R \& Dinevski, D. (2012). Virtual Laboratory in Chemistry - Experimental Study of Understanding, Reproduction and Application of Acquired Knowledge of Subject's Chemical Content. Organizacija, 4(3). https://doi.org/10.2478/v10051-012-0011-7

Hess, S. (2014). Digital Media and Student Learning: Impact of Electronic Books on Motivation and Achievement. New England Reading Association Journal. 49 (2), 35-39. Retrieved from https://www.semanticscholar.org/paper/...6fde1

Hidayati, H., \& Masril, M. (2019). Penggunaan LKM Untuk Menunjang Kegiatan Laboratorium Virtual Fisika Inti. Jurnal Penelitian Pendidikan IPA, 5(2), 149-153. https://doi.org/10.29303/jppipa.v5i2.250

KoliL, V. K., Muthupalani, S and Achuthan, K. (2020). Virtual experimental platforms in chemistry laboratory education and its impact on experimental self-efficacy. International Journal of Educational Technology in Higher Education. 17:30 https:// doi.org/10.1186/s41239-020-00204-3

Liu, D., Valdiviezo-Díaz, P., Riofrio, G., Sun, Y. Barba, R. (2015). Integration of Virtual Labs into Science E-learning. Procedia Computer Science. 75 (2015) p. 95 102. https:// doi.org/10.1016/j.procs.2015.12.224

Masril, M., Hidayati, H., \& Darvina, Y. (2018). Penerapan Discovery Learning Berbantuan Virtual 
LaboratoryUntuk Meningkatkan Kompetensi Fisika Siswa SMA. Jurnal Penelitian Pendidikan IPA, 5(1).

https://doi.org/10.29303/ippipa.v5i1.160

Orgaz, F., Moral., \& Dom'inguez, C. M. (2018). Student Attitude and Perception with The Use of Technology in The University. Journal of Educational Psychology Propositos Y Representaciones. 6(2): 277-299. Retrieved from https://eric.ed.gov/?id=EJ1196215

Putri, L. A., Permanasari, A., Winarno1, N., \& Ahmad, N. J. (2021). Enhancing Students' Scientific Literacy using Virtual Lab Activity with Inquiry-Based Learning. J. Sci. Learn. 4(2). 173-184. https://doi.org/10.17509/jsl.v4i2.27561

Ramadhan, M. F. \& Irwanto. (2017). Using virtual labs to enhance students' thinking abilities, skills, and scientific attitudes. International Conference on Educational Research and Innovation. https://doi.org/10.31227/osf.io/vqnkz

Sari, D.K., Permanasari, A., Supriyanti, F., M. (2017). Profile of students' creative thinking skills on quantitative project- based protein testing using local materials. Journal Pendidikan IPA Indonesias. 6(1).

71-75. https://doi.org/10.15294/ipii.v6i1.9516

Sari, D. K., Ibrahim, A., R., Wancik, K., A. (2018). Designing biochemistry project with local materials to increased student's creativity. The 3rd SULE-IC 2018.

Setiono. (2021). Analisis Respon Mahasiswa Dalam Pembelajaran Online Berbasis Aktifitas Di Perguruan Tinggi. Jurnal Pendidikan. 9(2). 15-21. https://doi.org/10.36232/pendidikan.v9i2.1095

Vasiliadou, R. (2020). Virtual laboratories during coronavirus (COVID-19) pandemic. Wiley Online Library, 48(5), 482-483. https://doi.org/10.1002/bmb.21407

Widowati, A., Nurohman, S., \& Setyowarno, D. (2017). Development of Inquiry-Based Science Virtual Laboratory for Improving Student Thinking Skill of Junior High School. Jurnal Pendidikan Matematika dan Sains, 5(2), 170-177. http://dx.doi.org/10.21831/jpms.v5i2.16708

Quesada, V. (2020). Virtual laboratory lessons in enzymology. Biochemistry and Molecular Biology Education, 48(5), 442-447. https://doi.org/10.1002/bmb.21394 